\title{
JEZIORO RADODZIERZ - PRZYKŁAD WYKLUCZAJĄCYCH SIĘ RODZAJÓW WŁASNOŚCI
}

\section{LAKE RADODZIERZ - ONE LAKE, TWO MUTUALLY EXCLUSIVE TYPES OF OWNERSHIP}

\author{
http://dx.doi.org/10.12775/PPOS.2014.004
}

\section{STRESZCZENIE}

Niniejsza praca przedstawia skomplikowaną kwestię własności jeziora Radodzierz. Przedmiotowe jezioro zostało jednocześnie sklasyfikowane jako „woda stojąca” oraz „woda płynąca”. Jest to niezgodne zarówno z punktu widzenia Prawa wodnego, jak i hydrologii. Zaistniały podział doprowadził do sytuacji, w której część jeziora uznana za „wodę płynącą” stanowi własność Skarbu Państwa, a część uznana za „wodę stojącą" jest własnością prywatną, co w połączeniu z charakterem przedmiotu tej własności, w sposób znaczący, utrudnia

* Magister prawa.

** Dr hab, prof. UMK - Kierownik Katedry Hydrologii i Gospodarki Wodnej Wydziału Nauk o Ziemi Uniwersytetu Mikołaja Kopernika w Toruniu. 
wykonywanie praw przysługujących każdemu właścicielowi. Istotny jest jednocześnie fakt, iż w niektórych kwestiach, prawa i obowiązki właścicieli jeziora różnią się od siebie, a ich wykonywanie przez jednego właściciela wpływa bezpośrednio na własność drugiego. Praca zawiera wieloaspektowe i szczegółowe omówienie komplikacji prawnych i faktycznych wynikających z takiej sytuacji, a ponadto wskazuje argumenty przemawiające za koniecznością sklasyfikowania jeziora Radodzierz jako „wody płynącej”.

\section{Słowa kluczowe}

Jezioro Radodzierz; własność Skarbu Państwa; własność prywatna; woda płynąca; woda stojąca.

\section{ABSTRACT}

The paper covers a complicated issue concerning the proprietorship of Lake Radodzierz. The discussed lake is at the same time classified as ,stagnant water' and ,flowing water'. It is at variance with the Act of 2001 on Water Law, as well as hydrology. As the result of the division, the part of the lake considered ,flowing water' is owned by the State Treasury whilst the part considered ,stagnant water' is private property, which in connection with the nature of this property, makes it significantly hard for both proprietors to exercise their rights. Another important fact is that in some matters regarding the management of the lake, rights and obligations of public and private owners are different, so actions undertaken by one owner almost always affect the ownership of the other one. This paper includes a detailed analyses of legal and factual complications resulting from the present situation. Moreover, it gives arguments for classifying Lake Radodzierz as „flowing water”.

\section{Keywords}

Lake Radodzierz; ownership of the State Treasury; private ownership; flowing water; stagnant water. 
Jezioro Radodzierz położone jest w północnej części województwa kujawsko-pomorskiego. Jego powierzchnia wynosi 246,4 ha $^{1}$, a objętość $12,33 \mathrm{mln} \mathrm{m}^{3}$, co czyni je dziesiątym pod względem powierzchni jeziorem w tym województwie. Należy ono również do najbardziej atrakcyjnych obiektów hydrologicznych tego regionu. W części południowej jezioro stanowi własność Skarbu Państwa (ok. 71\% powierzchni). Uprawniona do wykonywania tego prawa jest Agencja Nieruchomości Rolnych w Bydgoszczy. Z kolei część północna jeziora (ok. 29\% powierzchni) jest własnością prywatną (rys. 1). Istniejący podział dokonany według kryterium własności ma charakter sztuczny, a ponadto nie jest uwarunkowany jakimikolwiek zależnościami środowiskowymi. Część jeziora należąca do Skarbu Państwa oznaczona jest jako „woda płynąca”, natomiast część będąca własnością prywatną figuruje jako „woda stojąca”. Wyjaśnianie zaistniałej sytuacji i ostateczne zaszeregowanie jeziora trwa już wiele lat. Do pierwszego kwartału 2011 r. opracowano 4 ekspertyzy, z których dwie wskazywały, iż całe jezioro należy zakwalifikować jako „woda płynąca”, a dwie jako „woda stojąca”. Właściwy w sprawie Starosta uznał jezioro za „wodę płynącą”, jednak odwołano się od jego decyzji ${ }^{2}$. Sprawa nie została rozstrzygnięta ostatecznie do dnia dzisiejszego, przez co stan poważnego naruszenia przepisów Prawa wodnego trwa nadal.

1 Wg danych Instytutu Rybactwa Śródlądowego w Olsztynie. A. Choiński, Katalog jezior Polski, Poznań 2006, s. 175.

2 Protokół nr 5/11 posiedzenia Komisji Polityki Finansowej Rady Powiatu Świeckiego z dnia 29 marca 2011 r., [online], dostęp: 15.03.2014, <http:// bip.powiat.swiecki.lo.pl/?cid=928\&bip_id=7067>. 
Rysunek 1. Mapa fragmentu zlewni rzeki Mątawy i Dopływu z jeziora Radodzierz

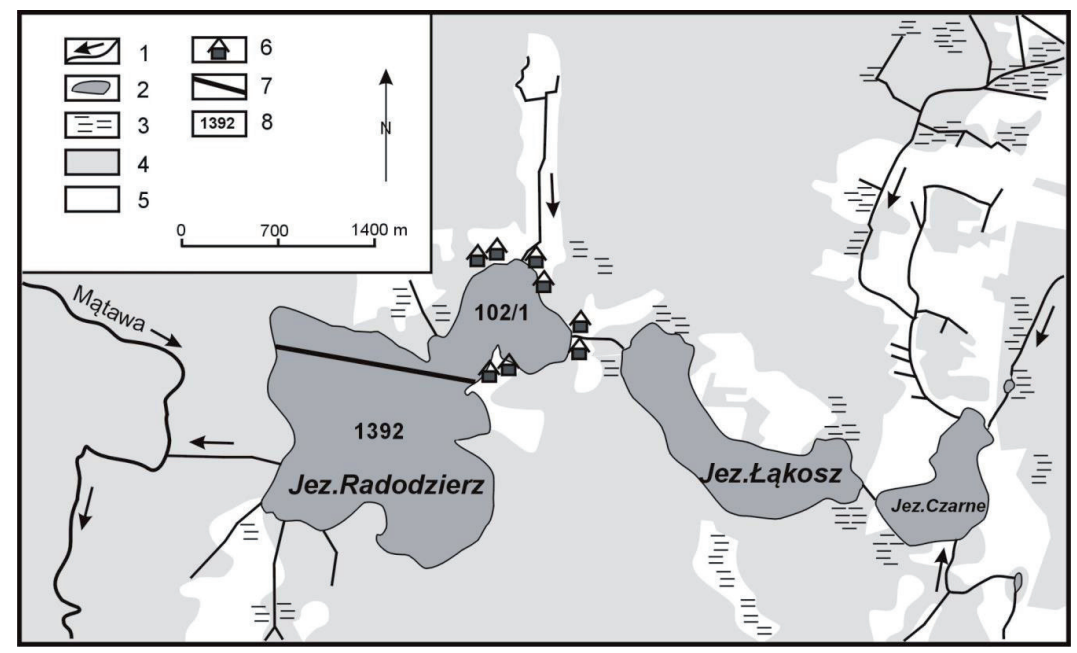

Objaśnienia: 1 - cieki; 2 - jeziora; 3 - mokradła; 4 - lasy; 5 - łąki i obszary rolnicze; 6 - ośrodki i domki wypoczynkowe; 7 - granica między działkami tj. obszarem „wody stojącej” i „wody płynącej”; 8 - numery działek.

Zgodnie z art. 10 ustawy z dnia 18 lipca 2001 r. Prawo wodne ${ }^{3}$, własność wód, w tym jezior, może przysługiwać Skarbowi Państwa, innym osobom prawnym albo osobom fizycznym. Ponadto, wody będące własnością Skarbu Państwa lub jednostek samorządu terytorialnego są wodami publicznymi i korzystanie $\mathrm{z}$ nich podlega rygorom przewidzianym $\mathrm{w}$ art. 34 Prawa wodnego. Kryterium decydującym o możliwości występowania jezior w obrocie cywilnoprawnym jest sklasyfikowanie ich jako „wody stojące”, czyli takie, które znajdują się w jeziorach niezwiązanych bezpośrednio, w sposób naturalny, z powierzchniowymi wodami płynącymi (art. 5 ust. 3 pkt 2 Prawa wodnego). 
To zaś implikuje kwestie dotyczące własności prywatnej (osób fizycznych lub osób prawnych) jezior. Podkreślić jednak należy, iż chodzi tutaj o każdą własność odrębną od Skarbu Państwa i jednostek samorządu terytorialnego, gdyż w obrębie art. 10 Prawa wodnego ustawodawca, w sposób niekonsekwentny, najpierw wskazuje, że wody mogą stanowić własność osób prawnych, a później zalicza wody będące własnością samorządów do własności publicznej ${ }^{4}$. Gmina, powiat oraz województwo mają bowiem, na mocy odpowiednich przepisów, osobowość prawną (ustawa z dnia 8 marca 1990 r. o samorządzie gminnym ${ }^{5}$, ustawa z dnia 5 czerwca 1998 r. o samorządzie powiatowym ${ }^{6}$ oraz ustawa z dnia 5 czerwca 1998 r. o samorządzie województwa ${ }^{7}$ ).

Zgodnie z Prawem wodnym jeziora nie mogą być własnością prywatną oraz nie mogą występować w obrocie cywilnoprawnym jeżeli są sklasyfikowane jako „woda płynąca” czyli posiadają ciągły bądź okresowy naturalny dopływ lub odpływ wód powierzchniowych (art. 5 ust. 3 pkt 1 lit. b Prawa wodnego). Pomimo, że przepis art. 10 ust. 2 stanowi ogólnie, iż własność wód może przysługiwać jednostkom samorządu terytorialnego (gmina, powiat, województwo), to jednak w obowiązującym stanie normatywnym, prawo własności wód płynących nie może im przysługiwać ${ }^{2}$. Reasumując powyższe należy wskazać, że obecnie tylko Skarb Państwa może być właścicielem jezior sklasyfikowanych zarówno jako „woda płynąca”, jak i „woda stojąca”. Jednostki samorządu terytorialnego oraz podmioty prywatne (osoby fizyczne lub osoby prawne), mogą być tylko właścicielami jezior uznanych za „wodę stojącą”.

Istotną dla omawianego problemu tezę zawiera wyrok Sądu Apelacyjnego w Szczecinie z dnia 22 listopada 2007 r. ${ }^{9}$

4 M. Kałużny, Prawo wodne. Komentarz, Warszawa 2012, s. 72.

5 Tj. Dz.U. z 2013 r. poz. 594, 1318.

6 Tj. Dz.U. z 2013 r. poz. 595, 645.

7 Tj. Dz.U. z 2013 r. poz. 596, 645.

8 B. Rakoczy [w:] B. Rakoczy (red.), Prawo wodne. Komentarz, Warszawa 2013, s. 76.

9 Sygn. akt I Aca 339/07, [online], dostęp: 11.03.2014, <http://bip. prokuratoria.gov.pl/download/Z2Z4L2JpcHByb2t1cmF0b3JpYS9wbC9kZWZhdWx0X29 waXN5Lzg1Mi85LzE/ 2007.11.22_iaca_339_07_sap.pdf>. 
Zgodnie z nią o charakterze wód nie decyduje możliwość percepcji stron umowy (podmiot publiczny i podmiot prywatny) ale obiektywny osąd tego charakteru, który uwzględnia stan rzeczywisty oraz obowiązujące przepisy. Ponadto sąd stwierdził, iż błędna klasyfikacja jeziora w ewidencji gruntów nie ma wpływu na klasyfikację zgodną z jego cechami, a wpisy w niej dokonywane mają charakter jedynie deklaratoryjny.

Wykonywanie prawa własności oraz innych praw rzeczowych na rzecz Skarbu Państwa w stosunku do mienia państwowego w rolnictwie zostało powierzone, zgodnie z ustawą z dnia 19 października 1991 r. o gospodarowaniu nieruchomościami rolnymi Skarbu Państwa ${ }^{10}$, Agencji Nieruchomości Rolnych (statio fisci), która jest państwową osobą prawną. Wykonuje ona, we własnym imieniu, zarówno prawa i obowiązki związane z władaniem powierzonymi składnikami mienia Skarbu Państwa w stosunku do osób trzecich, jak i obowiązki publicznoprawne związane z tymi składnikami.

\section{III}

Zlewnia jeziora Radodzierz, w której znajdują się jeszcze dwa inne jeziora (Łąkosz i Czarne) zajmuje obszar 34,17 km². Wszystkie te jeziora połączone są ciekiem o nazwie „Dopływ z jeziora Radodzierz" o długości 11,67 km. Ciek ten wypływa z mokradeł znajdujących się powyżej jeziora Czarne i stanowi połączenie między tymi jeziorami, a następnie odprowadza wody z jeziora Radodzierz (i tym samym z całej zlewni) do Mątawy. Odcinek cieku między jeziorami Łąkosz i Radodzierz ma charakter naturalny. Ciek płynie w zatorfionym, płaskim obniżeniu, którego szerokość osiąga 40-50 m (cecha ta jest typowa dla cieków naturalnych). Do ok. XIX wieku poziom lustra wody w tym cieku, a także w jeziorach, był wyższy o ok. 1,2 m. Obniżenie poziomu jezior związane było z pracami melioracyj-

10 Tj. Dz.U. z 2012 r. poz. 1187 z późn. zm. 
nymi prowadzonymi na obszarze Borów Tucholskich. Wyraźne cechy naturalności posiada także ciek płynący w szerokim, także zatorfionym obniżeniu między jeziorem Czarne a jeziorem Łąkosz. W korycie cieku widoczne są ślady jego oczyszczania, które miało przeciwdziałać powstawaniu cofki. Inny rodzaj ingerencji człowieka widoczny jest w pobliżu przepustu pod drogą gruntową. Naturalny charakter cieku łączącego poszczególne jeziora został wykorzystany do odprowadzania nadmiaru wód w wilgotnych okresach roku ze zmeliorowanych łąk. Największe ich obszary występują w górnej części zlewni, powyżej jeziora Czarne. Jezioro Radodzierz ma więc ciągły (stały) naturalny dopływ śródlądowych wód powierzchniowych płynących, który łączy także wyżej położone jeziora. Opisany stan faktyczny upoważnia do zakwalifikowania tego jeziora do wód płynących zgodnie z art. 5 ust. 1 Prawa wodnego.

W zlewni „Dopływu z jeziora Radodzierz” znajdują się również inne dowody potwierdzające słuszność powyższego wniosku. Aktualnie, odpływ wody z omawianego jeziora odbywa się poprzez sztuczny rów wykopany w XIX wieku podczas prac regulacyjnych recypienta - rzeki Mątawy. Rów ten łączy najkrótszą drogą jezioro Radodzierz z rzeką Mątawą i przecina naturalne wyniosłości terenu (cechy te są typowe dla cieku sztucznego). Regulacja rzeki Mątawy polegała m.in. na obniżeniu poziomu koryta i jego wyprostowaniu w celu osuszenia podmokłych łąk. Spowodowało to obniżenie poziomu wód podziemnych i zwierciadła wody w jeziorach wyżej położonych, o czym już pisano.

Wyraźny szlak odpływu naturalnego, dziś już nieczynnego, przebiega w odległości $150-200$ m na północ od cieku sztucznego. W jego dolnym odcinku zachowały się dobrze widoczne w terenie stare meandry (zakola), a ujściowy odcinek „zawieszony” jest ponad $1 \mathrm{~m}$ nad współczesnym poziomem rzeki Mątawy. Wskazane cechy są charakterystyczne wyłącznie dla cieków naturalnych. Stanowią one najlepszy dowód świadczący o naturalnej genezie odpływu z jeziora Radodzierz, który w XX wieku (być może pod koniec XIX wieku) zastąpiono sztucznym. Inne dowody potwierdzające naturalne cechy od- 
pływu z jeziora Radodzierz znaleźć można na archiwalnych materiałach kartograficznych.

Analizując położenie jeziora Radodzierz w systemie hydrograficznym, nie sposób pominąć faktu, że - oprócz dopływu głównego - posiada ono kilka krótkich, sztucznych, okresowych i uregulowanych dopływów z okolicznych mokradeł. Zakładając nawet ich antropogeniczne pochodzenie nie zmienia to faktu przepływowości jeziora Radodzierz z uwagi na naturalną genezę głównego dopływu i odpływu. Jezioro Radodzierz należy więc zaliczyć do śródlądowych wód powierzchniowych płynących, gdyż posiada ono naturalny dopływ, a naturalny odpływ został antropogenicznie zmieniony. W zlewni jeziora Radodzierz przeprowadzono w ostatnich ok. 150 latach szereg prac melioracyjnych głównie wzdłuż cieków lub ich fragmentów, które - zgodnie z Prawem wodnym - nie mogą jednak stanowić podstawy do odebrania temu jezioru kategorii śródlądowych wód powierzchniowych płynących. Powoduje to nie tylko istotne skutki prawne, ale także związane z ochroną tego ekosystemu. Niniejszą ocenę opracowano na podstawie treści zawartej w ekspertyzie dotyczącej klasyfikacji hydrologicznej jeziora Radodzierz ${ }^{11}$.

Z przedstawionych w sposób skrótowy informacji wynika, że zakwalifikowanie tego jeziora do odpowiedniego typu wskazanego w Prawie wodnym, a także wielu innych jezior, nie jest zadaniem łatwym. W zasadzie nie jest możliwe dokonanie tego w sposób kameralny, a więc z pominięciem przeprowadzenia obserwacji i pomiarów w terenie. Pomijając nawet ustalenia dotyczące typu jeziora Radodzierz, zgodnie z Prawem wodnym, nie jest do przyjęcia jego podział na część zakwalifikowaną jako „woda płynąca” i część jako „woda stojąca”.

Brak jednoznacznego statusu prawnego jeziora Radodzierz utrudnia jego prawidłowe wykorzystanie chociażby dla celów rekreacyjnych. Stan ekologiczny tego jeziora został

11 R. Glazik, W. Marszelewski, Ekspertyza dotycząca klasyfikacji hydrologicznej jeziora Radodzierz w rozumieniu Ustawy z dnia 18 lipca 2001 r. Prawo wodne. 
określony w 2007 roku przez Wojewódzki Inspektorat Ochrony Środowiska w Bydgoszczy jako dobry ${ }^{12}$. Utrzymanie dobrego stanu ekologicznego $\mathrm{w}$ przyszłości zależy m.in. od prawidłowo prowadzonej gospodarki rybackiej. Gospodarka ta, z uzasadnionych względów, prowadzona jest aktualnie przez Polski Związek Wędkarski Oddział w Bydgoszczy jedynie w południowej części jeziora. Istniejący podział jeziora utrudnia prawidłowe wykonywanie przedmiotowych działań. Kolejny problem stanowi korzystanie z północnej części jeziora przez turystów przebywających w kilku ośrodkach wczasowych, zlokalizowanych od wielu lat nad jeziorem. Bliższa analiza tego problemu wykracza jednak poza ramy niniejszego opracowania.

Należąca do Skarbu Państwa południowa część jeziora Radodzierz ma powierzchnię $1696786 \mathrm{~m}^{2}$ i zajmuje działkę o numerze 041411_2.0011.AR_20.1392, która znajduje na terenie powiatu świeckiego, $\mathrm{w}$ gminie Warlubie, w obrębie Lipniki. Z kolei północna część tego jeziora, stanowiąca własność prywatną, ma powierzchnię $757716 \mathrm{~m}^{2}$ i zajmuje działkę o numerze 0141406_5.0003.102/3. Działka ta znajduje się również na terenie powiatu świeckiego, ale już w gminie Nowe obszar wiejski ${ }^{13}$. Przebieg linii rozgraniczającej obie działki tego jeziora ma charakter umowny i nie jest odzwierciedlony w sposób fizyczny zarówno pod wodą, jak i nad jej lustrem. W związku z tym nie wpływa ona w jakikolwiek sposób na ekosystem jeziora, który funkcjonuje w sposób naturalny.

Zgodnie z art. 5 Prawa wodnego, jeziora mogą być uznane albo za „wodę stojącą" albo za „wodę płynącą". Powyższy podział ma charakter wyczerpujący i nie ma ani prawnej (sto-

12 Wojewódzki Inspektorat Ochrony Środowiska w Bydgoszczy, [online], dostęp: 14.03.2014, <http://www.wios.bydgoszcz.pl/webmapa/wody/ pdf/2007_12.pdf>.

13 Geoportal, [online], dostęp: 08.03.2014, <http://geoportal.gov.pl/>. 
sując kryteria podziału Prawa wodnego), ani fizycznej możliwości sklasyfikowania jakiegokolwiek jeziora, by czyniło ono równocześnie zadość wymaganiom zawartym w obrębie każdej ze wskazanych klasyfikacji. Spełnienie wymogów przewidzianych dla uznania jeziora za „wodę płynącą" automatycznie wyłącza wobec niego zastosowanie regulacji właściwej dla „wody stojącej” i odwrotnie. Brak fizycznej możliwości uznania jeziora za czyniące zadość obu kryteriom podziału opiera się na tym, iż Prawo wodne zaliczając wody (jeziora) do określonego rodzaju, posługuje się właściwymi dla nich cechami fizycznymi, które występują w środowisku naturalnym albo samoistnie albo w wyniku działań człowieka. W tym przypadku cechy fizyczne, mają niejako wtórny charakter w stosunku do prawa, które uznało je za wiążące dla rozgraniczenia obu rodzajów wód (jezior). Osobną, ale wyjątkowo istotną kwestią jest jednak odpowiedź na pytanie, czy właśnie te cechy mogą być uznane za decydujące oraz czy poszukiwanie i ich udowadnianie nie nastręcza trudności praktycznych, słowem czy zastosowane przez Prawo wodne kryterium podziału jezior jest właściwe ${ }^{14}$.

Wykonywanie prawa własności w odniesieniu do południowej części wód jeziora Radodzierz zostało powierzone Agencji Nieruchomości Rolnych w Bydgoszczy. Powierzenie przedmiotowych działań temu statio fisci jest rozwiązaniem właściwym, gdyż w omawianym stanie faktycznym nie znajdzie zastosowania art. 11 ust. 1 pkt 2 lit. b i c Prawa wodnego, na mocy którego prawa właścicielskie w stosunku do wód publicznych stanowiących własność Skarbu Państwa wykonuje Prezes Krajowego Zarządu Gospodarki Wodnej. Wskazana regulacja, co prawda, dotyczy „wód płynących”, ale tylko tych, które są istotne dla kształtowania zasobów wodnych oraz ochrony przeciwpowodziowej. Wody jeziora Radodzierz oraz rzeka Mątawa, do której one uchodzą, nie figurują w załączni-

14 Szerzej w kwestiach klasyfikacji jezior zgodnie z Prawem wodnym oraz problematyką ich własności: M. Marszelewski, W. Marszelewski, Problemy własności jezior w Polsce, „Przegląd Prawa Ochrony Środowiska” 2013, nr 3, s. 29-45. 
ku nr 1 do rozporządzenia Rady Ministrów z dnia 17 grudnia 2002 r. w sprawie śródlądowych wód powierzchniowych lub ich części stanowiących własność publiczną ${ }^{15}$. Zgodnie z $\S 1$ pkt 1 tego aktu, określa on śródlądowe wody powierzchniowe lub ich części stanowiące własność publiczną, istotne dla kształtowania zasobów wodnych oraz ochrony przeciwpożarowej. Ustawowa delegacja do wydania przez Radę Ministrów powyższego rozporządzenia została zawarta w art. 11 ust. 2 Prawa wodnego, co każe przyjąć, iż jest ono wyłącznie wiążące w kwestii wykonywania praw właścicielskich przez Prezesa Krajowego Zarządu Gospodarki Wodnej w odniesieniu do jezior spełniających wymagania zawarte $\mathrm{w}$ art. 11 ust. 1 pkt 2 lit. b i c tego aktu normatywnego. Wskazany problem nie ma charakteru jedynie teoretycznego, ponieważ w praktyce zdarzają się przypadki, iż uprawnienia właścicielskie są wykonywane przez niewłaściwe podmioty ${ }^{16}$.

Uprawnionym do rybactwa na jeziorze Radodzierz (obwód rybacki nr 370a, nazwany „Obwód rybacki jeziora Radodzierz na cieku bez nazwy w zlewni rzeki Mątawa”) jest dyrektor Regionalnego Zarządu Gospodarki Wodnej (RZGW) w Gdańsku. Figuruje on w kolumnie „nazwa użytkownika” ${ }^{17}$ Zgodnie z art. 13 ust. 2 Prawa wodnego, należące do Skarbu Państwa, publiczne śródlądowe wody powierzchniowe płynące, dyrektor RZGW oddaje do rybackiego korzystania w drodze oddania w użytkowanie obwodu rybackiego ustanowionego na podstawie ustawy o rybactwie śródlądowym. Umowa taka jest umową nazwaną i konsensualną. Ponadto zawarta jest na czas określony, ale nie krótszy niż 10 lat (art. 13. ust. 3 Prawa wodnego). Zgodnie z postanowieniem Wojewódzkiego Sądu Administracyjnego w Gdańsku z dnia 28 czerwca 2005 r.

15 Dz.U. z 2012 r. Nr 16, poz. 149.

16 W tej kwestii wypowiedział się Sąd Okręgowy w Gdańsku w Postanowieniu z dnia 15 stycznia 2009 r. Sygn. akt III Ca 1036/08, [online], dostęp: 15.03.2014, <http://bip.prokuratoria.gov.pl/orzeczenia_wydane_w_sprawach_pro/2009/01_styczen/15/>.

${ }_{17}$ Regionalny Zarząd Gospodarki Wodnej w Gdańsku, [online], dostęp: 15.03.2014, <http://www.rzgw.gda.pl/cms/fck/uploaded/ZR/050214wykazuzytkownikow.pdf $>$. 
„Oddawanie w użytkowanie obwodów rybackich przez organy administracji publicznej odbywa się według reguł cywilnoprawnych, a nie przez jednostronne władcze rozstrzygnięcia tych organów (art. 13 ust. 3 i 5 ustawy z dnia 18 lipca 2001 r. Prawo wodne, Dz.U. Nr 115, poz. 1229 ze zm.)"18. Ponadto w literaturze przedmiotu, słusznie wskazuje się, że analizowana umowa przypomina konstrukcyjnie umowę dzierżawy, a użycie terminu „użytkowanie”, z uwagi na fakt, iż dotyczy ono ograniczonego prawa rzeczowego uregulowanego w art. 252 Kodeksu cywilnego ${ }^{19}$, jest niewłaściwe. Dodatkowo art. 13 ust. 8 Prawa wodnego odsyła do odpowiedniego stosowania przepisów Kodeksu cywilnego, jednakże nie mogą to być przepisy o użytkowaniu (ograniczone prawo rzeczowe), a użytkowanie obwodu rybackiego następuje na podstawie umowy, chodzi więc o odpowiednie stosowanie przepisów o umowach ${ }^{20}$.

Użytkownikiem należącej do Skarbu Państwa części jeziora Radodzierz, na zasadzie umowy dzierżawy, jest Polski Związek Wędkarski Oddział w Bydgoszczy. Oddanie przedmiotowych wód właśnie w dzierżawę (a nie umowę o użytkowanie obwodu rybackiego) może tłumaczyć fakt, zgodnie z którym PZW Oddział w Bydgoszczy nie figuruje jako użytkownik obwodu rybackiego nr 370a. Ponadto w wykazie wód Oddziału PZW w Bydgoszczy, pod numerem 63, znajduje się informacja o posiadaniu prawa do $2 / 3$ jeziora Radodzierz (Gmina Nowe - obszar wiejski) ${ }^{21}$. Jest ono wykonywane na „wodach płynących" - tj. 169, 46 ha.

18 Sygn. akt II SA/Gd 188/05, „Orzecznictwo Naczelnego Sądu Administracyjnego i Wojewódzkich Sądów Administracyjnych” 2006, nr 2, poz. 59.

19 Tj. Dz.U. z 2014 r. poz. 121.

20 B. Rakoczy, op.cit., s. 92-93.

21 Okręg Polskiego Związku Wędkarskiego w Bydgoszczy, [online], dostęp: 15.03.2014, <http://www.opzw.bydgoszcz.pl/index.php/wykaz-wod93/587-wykaz-wod-w-ramach-jednego-jeziora-2013-r.html>. 


\section{V}

Ustawa z dnia 18 kwietnia 1985 r. o rybactwie śródlądowym $^{22}$ (dalej u. r. ś.), w art. 15 ust. 1 przyznaje dyrektorowi RZGW kompetencję do ustanawiania i znoszenia, w drodze uchwały, obwodów rybackich. Została ona zrealizowana m.in. w rozporządzeniu nr 8/2012 Dyrektora Regionalnego Zarządu Gospodarki Wodnej w Gdańsku z dnia 21 września 2012 r. ${ }^{23}$ zmieniającym rozporządzenie nr 1/2003 Dyrektora Regionalnego Zarządu Gospodarki Wodnej w Gdańsku z dnia 5 listopada 2003 r. w sprawie ustanowienia obwodów rybackich ${ }^{24}$. Zgodnie z $§ 1$ pkt 151 rozporządzenia nr 8/2012 w załączniku do rozporządzenia 1/2003 dodaje się lp. 370a, pod którą, jako „nazwa obwodu” widnieje „Obwód rybacki jeziora Radodzierz na cieku bez nazwy w zlewni rzeki Mątawa”. Ponadto, zgodnie z rubryką „skład obwodu” obejmuje on „wody jeziora Radodzierz oraz wody dopływu do tych wód". Zaistniała sytuacja jest wyjątkowo ciekawa, ponieważ obwód rybacki omawianego jeziora jest ustanowiony dla niego jako całości i nie rozróżnia faktu, zgodnie z którym północna część tego jeziora jest własnością prywatną. Dyrektor RZGW nie ma kompetencji do ustanowienia obwodu rybackiego na wodach prywatnych (północna część jeziora Radodzierz), ponieważ takie obwody mogą być ustanawiane tylko na publicznych śródlądowych wodach powierzchniowych płynących (art. 12 ust. 1 u. r. ś.). Ustanowienie obwodu rybackiego na całym jeziorze Radodzierz skutkuje koniecznością wykupywania kart wędkarskich. Oznacza to, iż każda osoba łowiąca ryby zobowiązana jest do posiadania karty wędkarskiej bez względu na to, w której części jeziora dokonuje połowu.

Wskazana sytuacja ma ponadto doniosły wymiar praktyczny, gdyż uprawniony do rybactwa sporządza operat rybac-

22 Tj. Dz.U. z 2009 r. Nr 189, poz. 1471 z późn. zm.

23 Dz.Urz. Woj. Kujawsko-Pomorskiego z 2012 r., poz. 1984.

24 Dz.Urz. Woj. Kujawsko-Pomorskiego z 2003 r. Nr 149, poz. 2010 z późn. $\mathrm{zm}$. 
ki, który określa zasady prowadzenia racjonalnej gospodarki rybackiej w obwodzie rybackim (art. 6a u. r. ś.). Operat rybacki decyduje m.in. o prowadzeniu połowów ryb czy wielkości i strukturze zarybień. Ponadto warto wspomnieć choćby jeszcze o art. 13 ust. 1 Prawa wodnego, który również nie może być stosowany bez przeszkód. Zgodnie z nim właściciel wody jest uprawniony do pobierania jej pożytków. Zalicza się do nich ryby oraz inne organizmy żyjące w wodzie. Jak zatem należy prowadzić wskazane działania w odniesieniu do jeziora Radodzierz w sytuacji, w której ichtiofauna oraz inne organizmy żyjące w wodzie, co oczywiste, granicy nie uznają?

Prawo wodne, w art. 26, zawiera zamknięty katalog obowiązków właściciela śródlądowych wód powierzchniowych, które są niezależne od sklasyfikowania wody jako „woda płynąca” lub „woda stojąca”. Należą do nich m.in. zapewnienie należytego stanu technicznego koryt cieków naturalnych oraz kanałów, dbałość o utrzymanie dobrego stanu wód, regulowanie stanu wód lub przepływów w ciekach naturalnych czy współudział w odbudowywaniu ekosystemów zdegradowanych przez niewłaściwą eksploatację zasobów wodnych. W tym przypadku również nasuwa się pytanie w kwestii właściwej (wspólnej?) realizacji powyższych obowiązków przez obu właścicieli jeziora. Zwłaszcza że przepis ma zastosowanie bez względu na klasyfikację wód, jednakże wydaje się, że przedmiotowe obowiązki mogą różnić się od siebie, chociażby intensywnością, w odniesieniu do „wody płynącej” bądź „wody stojącej".

Przedstawiona sytuacja, w odniesieniu do części jeziora Radodzierz należącej do Skarbu Państwa, implikuje również konieczność zastosowania regulacji zawartych w art. 34 Prawa wodnego. Dotyczą one powszechnego korzystania z wód i określają istotę oraz jego zakres podmiotowy i przedmiotowy.

Powszechne korzystanie z wód (publicznych) przysługuje każdemu i służy do zaspokajania potrzeb osobistych, gospodarstwa domowego lub rolnego, bez stosowania specjalnych urządzeń technicznych, wypoczynku, uprawiania turystyki, sportów wodnych oraz, na określonych zasadach, amatorskiego 1/2014 połowu ryb (art. 34 ust. 1 i 2 Prawa wodnego). W piśmiennic- 
twie słusznie podkreśla się, że uprawnienie to dotyczy również przedsiębiorstw rolnych, które pobierają wodę bez specjalnych urządzeń technicznych tj. pompy, rury ciągowe czy wieże ciśnieńn ${ }^{25}$. Artykuł 34 ust. 3 wskazuje, jakie zachowania nie są objęte powszechnym korzystaniem $\mathrm{z}$ wód. Jest to katalog o charakterze zamkniętym, który, z uwagi na fakt wprowadzania wyjątków oraz ograniczeń praw i wolności jednostki, powinien być interpretowany ścieśniająco ${ }^{26}$. Dla analizowanego przypadku zastosowanie będą miały zakazy wycinania roślin z wód lub brzegu oraz wprowadzania ścieków. Ponadto art. 34 ust. 4 zezwala na wydobywanie, w granicach powszechnego korzystania z wód, kamienia, żwiru, piasku oraz innych materiałów, po uzyskaniu zgody właściciela wody, w miejscach wyznaczonych przez radę gminy w drodze uchwały. Stosując regułę wykładni lege non distinguente, należy wskazać, iż przepis ten dotyczy zarówno wód publicznych („płynące” i „stojące”), jak i wód niepublicznych (,stojące”). Stanowisko to potwierdza brzmienie art. 35 prawa wodnego, zgodnie z którym $\mathrm{w}$ celu zaspokajania niezbędnych potrzeb społecznych, rada powiatu $\mathrm{w}$ drodze uchwały może wprowadzić powszechne korzystanie z wód powierzchniowych innych niż wymienione w art. 34 ust. 1 Prawa wodnego. Ma ono służyć zaspokajaniu potrzeb osobistych, gospodarstwa domowego lub rolnego. Aby móc zastosować przewidziane w art. 34 ust. 4 Prawa wodnego „zezwolenie” konieczne jest łączne spełnienie dwóch warunków przewidzianych w tym przepisie. Są to zgoda właściciela wody oraz, mająca charakter konstytutywny, uchwała rady gminy określająca miejsca wyznaczone do pobierania kamienia, żwiru, piasku oraz innych materiałów ${ }^{27}$. Wskazane problemy mogą skutkować powstaniem sporów między właścicielami obu części jezior.

25 J. Szachułowicz, Prawo wodne. Komentarz, Warszawa 2010, s. 131.

26 B. Rakoczy, op.cit., s. 185.

27 Szczegółową analizę przedmiotowej kwestii przeprowadza B. Rakoczy. Ibidem, s. 185-186. 


\section{VI}

Celem niniejszego artykułu nie jest wskazanie wszelkich możliwych sprzeczności mogących wystąpić podczas gospodarowania jeziorem Radodzierz w zaistniałym układzie jego własności. Wiele powstałych trudności trzeba rozwiązywać ad casum, w zależności od sytuacji, dlatego autorzy skupili się na kwestiach najważniejszych i najpowszechniejszych, niemniej wysoce problematycznych.

Analizowany, sztuczny podział jeziora Radodzierz jest zarówno z prawnego, jak i hydrologicznego punktu widzenia niewłaściwy. Nie tylko prowadzi on do szeregu niepożądanych rozstrzygnięć dotyczących stosowania prawa, ale jak wskazano, ma też podłoże praktyczne związane z koniecznością odpowiedniego gospodarowania tym jeziorem. Niemożliwe do odzwierciedlenia fizycznego „połączenie” własności Skarbu państwa oraz własności prywatnej wespół z charakterem i specyfiką przedmiotu tej własności jest dlań szkodliwe i może prowadzić do szeregu trudnych do rozstrzygnięcia napięć pomiędzy wykonującymi swe prawa właścicielami. Należy podkreślić, że naturalną właściwością jeziora jest to, iż praktycznie każde działanie (zaniechanie) jednego właściciela odbija się na własności drugiego. W analizowanym przypadku znaczącą rolę odgrywa fakt, zgodnie z którym właściwa i prawidłowa gospodarka wodami publicznymi wymaga określonych działań. Są one niekiedy inne niż te dotyczące własności prywatnej.

Wskazana sytuacja jest przede wszystkim wynikiem niewłaściwego stosowania prawa, które ponadto nie przystaje do przedmiotu swojej regulacji.

\section{BIBLIOGRAFIA}

Choiński A., Katalog jezior Polski, Poznań 2006.

Glazik R., Marszelewski W., Ekspertyza dotyczaca klasyfikacji hydrologicznej jeziora Radodzierz w rozumieniu Ustawy z dnia 18 lipca 2001 r. Prawo wodne. 
Kałużny M., Prawo wodne. Komentarz, Warszawa 2012.

Marszelewski M., Marszelewski W., Problemy własności jezior w Polsce, „Przegląd Prawa Ochrony Środowiska” 2013, nr 3, s. 29-45.

Protokół nr 5/11 posiedzenia Komisji Polityki Finansowej Rady Powiatu Świeckiego z dnia 29 marca 2011 r., [online], dostęp: 15.03.2014, <http://bip.powiat.swiecki.lo.pl/?cid=928\&bip_ $\mathrm{id}=7067>$.

Rakoczy B. (red.), Prawo wodne. Komentarz, Warszawa 2013.

Szachułowicz J., Prawo wodne. Komentarz, Warszawa 2010.

Kontakt e-mail:

marszelewski@gmail.com 